\title{
Placing the Blame in the Post-Ferguson Era: An Exploration of Police Attributions for Crime, Their Declining Legitimacy, and the Breakdown of Justice
}

\author{
Adam Dobrin ${ }^{1}$ \\ Florida Atlantic University, USA \\ Seth Wyatt Fallik \\ Florida Atlantic University, USA \\ Ross Deuchar \\ The University of the West of Scotland \\ Vaughn J. Crichlow \\ Florida Atlantic University, USA \\ Sierra Harris \\ Nova Southeastern University, USA
}

\begin{abstract}
This paper explores police perceptions on the causes of crime and the declining legitimacy of the police. Notwithstanding the growing body of research on public perceptions towards police, there is little qualitative research on the police perceptions on their attributions for crime, their declining legitimacy, and the breakdown of justice. It is crucial to increase knowledge on police perceptions towards the public, particularly in the aftermath of violent police-citizen encounters. Given the likelihood that such perceptions will influence the behavior of police officers when interacting with the public, exploring police perspectives regarding crime, their declining legitimacy, and the breakdown of justice is a worthy endeavor. This study, therefore, presents qualitative analysis of data gathered from interviews of 20 local police officers and deputies and participant observations conducted in a Southern American State. The study found that officers blamed community members and dysfunctional social institutions for sustaining environments that foster criminality, a lack of respect for authority, as well as declining police legitimacy. Officers were also frustrated by the role of news and social media as instigators of the constant anger and criticism towards police that make it difficult for them to do their jobs effectively. The implications for police practice and community relations are discussed.
\end{abstract}

KEYWORDS: Community Relations, Police Legitimacy, Post-Ferguson, Public Perceptions.

\footnotetext{
${ }^{1}$ Corresponding Author E-mail: adobrin@fau.edu
} 
Public perceptions towards police have garnered much attention in recent years, particularly in the aftermath of violent interactions between police and residents in racial and ethnic minority communities. The nature of public perceptions about police have been well documented, unfortunately the perceptions of police toward the public are not as well known. (Bates, Antrobus, Bennett, \& Martin, 2015; Carr \& Maxwell, 2018). As such, there has been a growing academic interest in surveying police offices (Morin, Parker, Stepler, \& Mercer, 2017; Nix, Pickett, Baek, \& Alpert, 2017; Nix, Pickett, \& Wolf, 2020). Their findings have shown that public scrutiny on police through various forms of traditional and non-traditional media- such as social media- (Perry, 2009, Bonilla \& Rosa 2015, Intravia, Wolff, \& Piquero, 2018), are likely to have a long-term impact on how both the public feel about the police and, of related interest to the current paper, how the police feel about the public.

It is, therefore, concerning how public outrage affects police perceptions of the public, and such perceptions are critical to study due to their tendency to guide behavior (Ajzen \& Fishbein, 1977). Furthermore, the perceptions held by police may guide their behavior in interactions with the public (Jackson \& Wade, 2005; Jackson, Bradford, Kuha, \& Hough, 2015), and this is an important concern given the frequency of reports on police violence perpetrated against black residents. The incident on August 9, 2014, in Ferguson, Missouri can be described as a historical marker that underlines an era of viral videos of officers appearing (and in some instances actually) using excessive force. In Ferguson, bystanders reported that Michael Brown (an unarmed, young, black, man) had his hands up, was facing away from Officer Daren Wilson, and following his commands when he was shot; facts later disputed in a Department of Justice (2015) investigation that exonerated Officer Wilson of wrongdoing. Mr. Brown succumbed to his injuries and these events promoted significant social unrest in the US that persists today (Adams, 2019; Campbell, Nix \& Maguire, 2018). The national rancor that was sparked by this incident is like the public response to the killing of George Floyd in Minneapolis and could lead to even more dramatic and sustained activism for racial justice (Daragahi, 2020). Such activism may have a further impact on officer perceptions and behavior. With these issues in mind, this paper seeks to increase knowledge on police perceptions of the public in the post-Ferguson era. In particular, this study examines police officer assessments on the causes of crime and the challenges of policing in a social environment that may be characterized by declining support for police and the breakdown of justice.

\section{Literature Review}

As suggested previously, police perceptions toward the community can have an influence on officer behavior when interacting with the community. Jackson and Wade (2005) present an important example of this in their finding that the greater the police perception of crime in a neighborhood, the more likely they are to engage in proactive styles of policing (although recent governmental responses to police actions, such as the filing of capital murder charges against Atlanta police officers by the local District Attorney for a controversial defensive shooting might be a bellwether event that reverses such activities). The issues of how fairly the police see their treatment is also important, often discussed as "legitimacy" and "procedural justice." Legitimacy is the combination of the public "support for legal authorities" and the obligation of the public to obey police directions (Tyler, 2004). Procedural justice (Tyler, 1990, 2006; Tyler and Blader, 2000), has been conceptualized into: 1 . being fair in processes; 2 . being transparent in actions; 3 . providing opportunity for voice; and 4. being impartial in decision making (U.S. Department of Justice, Office of Community Oriented Policing Services, 2021). More recent discourse also posits that the public judge police legitimacy on how fair it appears (as seen in procedural justice), the 
perception of the fair allocation of outcomes, and also the effectiveness and lawfulness of the police (Sun, et al., 2018; Jackson, \& Bradford, 2019). Huq et al (2017) summarize legitimacy as "an overarching belief that legal authorities act according to societal expectations of rightful conduct in their use of authority" (p. 1103).

Additional findings suggest that officers perceiving greater public antipathy have increased amounts of "work-group solidarity, cynicism toward the public, and coercive attitudes" (Marier \& Moule, 2019, p. 836; see also Muir, 1977; Niederhoffer, 1967; Skolnick, 2011). Marier and Moule (2019) note that police perceptions of hostility from the public are likely to have unforeseen impacts on police thoughts and actions, which may be, as noted by the President's Task Force on $21^{\text {st }}$ Century Policing (2015), counter to key elements of modern police reform, including transparency, police-community partnerships, and de-escalation of force. Unsurprisingly, the current sociopolitical climate has been found to affect officers' perceptions on a range of issues (Mourtgos \& Adams, 2019). Recent studies find that perceptions of excessive scrutinization of police have significant impact on their stress (Adams \& Mastracci, 2019; Saunders et al., 2019). Of great importance, however, is that police perceptions about public antipathy might likely be inaccurate and exaggerated, driven by media attention and not actual public perceptions (Nix \& Wolfe, 2016; Nix \& Pickett, 2017; Nix, Pickett, \& Wolf, 2020)). To that end, the public is likely to have more positive attitudes about the police than the police perceive (Cordner, 2017).

In the US, police interact with roughly a fifth of the population aged 16 or older each year, or about 53.5 million people/contacts. The contacts are officer initiated, most frequently for traffic stops, and also 'resident' initiated, primarily after reporting a crime, disturbance, or suspicious activity to police (Davis, Whyde, \& Langton, 2018). It would seem that frequent interactions with the public would create a reasonable sample size for the development of stable and accurate perceptions about the public, but early research on the topic of police perception of the public noted that like most people, police often have selective perception, confirmation and negativity bias. Negativity bias means that for most people in most situations, unpleasant events are remembered more strongly than other types of memories (see Rozin \& Royzman, 2001). Officers are more likely to remember unpleasant interactions with the public than pleasant ones, so the much more frequent pleasant encounters are overshadowed by the less frequent unpleasant ones (Klayman \& Ha, 1987; Trope \& Bassok, 1982; Worden, 1994). For example, in one of the original works on this topic, Westley (1970) found that nearly three quarters of police felt that the public were against them, and just $12 \%$ felt the public liked them. This is likely due to the fact that police often "exaggerate the extent of citizen hostility" (Wilson, 1973, p. 28), and combined with selective perception and confirmation bias, create a self-perpetuating set of negative perceptions of the police about the public.

Contrary to those findings, more recent research finds that a majority of officers report a generally positive view of the public, and their attitudes have generally become more positive in recent years, even after the national furor resulting from a series of highly publicized controversial deaths of racial and ethnic minorities at the hands of law enforcement officers. Roughly 70 percent of officers believe that most people respect the police, reject the idea that most people cannot be trusted, and that residents of the neighborhoods in which they work share their values (Morin et al., 2017). Similar to these findings, the public generally holds stable positive feelings towards the police (with variation by race, ethnicity, and political affiliation) (Fingerhut, 2017), and many members of the public are more willing to cooperate with police than the police perceive (Bates et al., 2015). And although the inclusion of police in the recent honoring of heroes during the COVID-19 pandemic may increase public support for law enforcement, police action during the pandemic may also have tarnished their reputations given the widely reported images of heavy- 
handedness in response to members of the public violating stay-at-home or social distancing orders (Namli, 2021; Johnson, 2020; White \& Fradella, 2020).

In spite of these optimistic findings, the impact of police-involved shootings should not be underestimated. In the largest nationally representative survey of police officers from agencies with at least 100 officers, research by the National Police Research Platform for the Pew Research Center notes that the majority of police officers point to recent high-profile fatal encounters between black citizens and police officers for increasing the risk of their jobs, and aggravating tensions between police and racial and ethnic minority communities. This leads police to report that they are reluctant to fully carry out some of their duties (Morin et al., 2017). About three quarters of the respondents in this survey thought that high-profile encounters have increased tensions between police and black communities. Roughly the same number of responding officers said that officers within their department are less likely to stop and question suspicious people, and there is roughly a consensus, almost ninety percent, who say that as a result of these high-profile incidents, police work has become more difficult.

This seminal survey also reports that the police often agree with public sentiments, but also have stark disagreements. For example, both the police and public support the police adoption of body worn cameras (66\% of officers and $93 \%$ of the public), that marijuana laws be relaxed (68\% of police and $84 \%$ of the public), as compared to most police thinking there needs to be more police on the street to ensure public safety, whereas the public disagrees. Similarly, about sixty-five percent of the public supports some sort of a ban on assault weapons, while roughly the same percentage of police oppose such a restriction. Stark differences also appear when comparing important issues of policing. More than eighty percent of the public say they understand the risks and rewards of police work well, but an almost equal proportion of police say the public does not (Morin et al., 2017). Most illustrative of the gap between police perceptions and those of the public revolve around the topic of the police killings of racial and ethnic minorities that lead to civil unrest. About two-thirds of police feel that these are "isolated incidents and not signs of broader problems between police and the black community" (pg. 5), while around sixty percent of the general public feel these killings are symptoms of a deeper problem.

While the police have traditionally been viewed as a homogenous group with stable and shared beliefs among all members, it is important to note that police officers are actually a heterogeneous group of individuals (Paoline, 2003). Furthermore, recent research notes that police are not a monocultural entity with shared perceptions and attitudes (Paoline, 2004; Ingram, Paoline, \& Terrill, 2013; Paoline \& Gau, 2018). Police perceptions are not standard across individuals or even agencies (Gaub, Choat, Todak, Katz \& White, 2016; Marier \& Moule, 2019). Variations in perceptions may be individual, but also influenced by factors that influence non-police perceptions, such as age, race, and gender. For example, Ioimo, Becton, Meadows, Tears, and Charles (2009) found significant differences between white and black officers, as well as between patrol-level officers, mid-level, and senior level officers on issues concerning biased-based policing.

Length of time as an officer can also greatly impact an officer's beliefs, which in turn can impact their treatment of arrestees (Rouhania, Gudlavalletib, Atzmonc, Park, Olsond, \& Sherman, 2019). Police perceptions concerning the public are also not monolithic (Mourtgos \& Adams, 2019), and vary greatly by individual and demographic characteristics. Furthermore, a key factor in the rubric of police treatment of the public is how the police feel they are treated by their own organization, and officers' perceptions of how fairly they are treated by their organizations may impact their trust in the public (Carr \& Maxwell, 2018). In addition, perceptions of being treated in a just manner by their employing organization increases the officers' trust in the public, regardless of officer ethnicity, gender, or age. 
In sum, prior research suggests that police officer perceptions could be influenced by a range of factors, and there could be a diversity of salient and instructive viewpoints within the law enforcement community. Declining legitimacy is not unique to the US, as many countries are also experiencing challenges to police authority (see Deuchar, Crichlow, \& Fallik, 2020; Lee, \& McGovern, 2013; Murray \& Harkin, 2017; Stamati, Papadopoulos, \& Anagnostopoulos, 2015). Yet, despite the growing body of research on the perceptions of police on various topics, there is a dearth in the literature concerning the perceptions of police on their apparent declining legitimacy along with the causes of crime in the midst of increasing public scrutiny and antipathy. This study seeks to make a modest contribution in this area by examining qualitative data from interviews with frontline police officers in the post-Ferguson era.

\section{Methodology}

In this exploratory study, local police officers and county deputies in a Southern American State were observed and interviewed to determine how the "Ferguson Effect" has impacted officer confidence, morale, and policing strategies. Interviews were conducted in two different counties within the Southern state by a single researcher. These counties were selected as convenience sample, due to both the proximity to the researchers and the professional relationships researchers had developed with leadership within the agencies. The counties contain approximately 1.8 million residents with a median household income of around fifty thousand dollars. Most registered voters of both counties belong to the Democratic Party, while the racial/ethnic demographics of these communities are consistent with the national rates. According to the U.S. Census Bureau (2017), the national racial/ethnic composition is as follows: White 61.3\%; Hispanic/Latino 17.8\%; Black 13.3\%; Asian 5.7\%. Both counties have crime rates below the national average across all index crimes and, in some cases, half the national rate.

For the duration of three months in the beginning of 2017, the same researcher shadowed specialized teams of frontline officers from each county utilizing an ethnographic approach. The 'participant as observer' role was incorporated, followed by in-depth interviews (Hammersley, 2006). To clarify: in the first stage, the researcher (observer) did not participate in any policing activities, while the police officers were aware that they were being observed. By participating alongside officers in their daily routines, trusting relationships were formed. These relationships provided a unique opportunity to gain informal insight before conducting additional in-depth interviews. The researcher had the opportunity to participate in the following field assignments: ride-alongs, covert surveillance work, pre-deployment briefings, and rest breaks alongside officers and sheriff deputies of various ranks. During these observations, brief notes of behaviors and conversations were routinely taken and transcribed. These were later utilized to aid in recollecting events, providing a more detailed observational accounting. Personal impressions and feelings were also noted to aid in the recollection of events (Emerson, Fretz, \& Shaw, 1995). Throughout this process, the researcher remained transparent in communicating the present project intentions to the participants. To recruit participants for interviews, the observer first approached individuals that had completed ride-alongs. Most officers who were invited to participate were willing to do so, although a few officers could not participate due to a lack of availability. Participation to the study was voluntary, meaning officers were not obligated to partake. Officers who took part in the study were informed that they could stop participating at any time. This information was provided to them in the consent form, which was presented prior to beginning the study.

Access to officers was obtained through the use of gatekeepers: contact was initially made with senior officers who had existing relationships with the host academic institution. Based on the observer's previous successful experiences with officers, which include shadowing and building 
positive relationships, the researcher was quickly welcomed by officers and successfully embodied the marginal native role, producing a balance between being a stranger and a colleague (Hammersley \& Atkinson, 2007). Once trust was built between the observer and officers, a snowball sampling method was utilized. Through established trust, officers recommended fellow employees to participate in the study, which provided a greater number of observations. This snowball sampling method was utilized until data saturation was reached (Strauss \& Corbin, 1998). Gaining participant trust contributed to the insightful formal and informal dialogues with officers, in addition to allowing them to share their opinions and insights without repercussions.

A total of 20 officers, varying in rank and length of service, participated in the study. The officers observed and interviewed represented a range of ranks, from unranked patrol to Chief, with nine (45\%) holding some level of leadership rank. Most served in a specialized unit (16 or 80\%), with 17 serving the same county and the remaining from another. Eighty percent (16) were white, 4 African American (two officers, 1 Lieutenant, and 1 Agent) and ninety percent (18) were male, consistent with the composition of most police departments in the US (Bureau of Justice Statistics 2013). One female participant had recently accepted the assignment of Departmental Chief of Police, the other female participant was a frontline officer. The most junior officer, in terms of length of service, had slightly over 4 years of service, while the most senior officer had over 40 years of service. Interviews were conducted with three executive officers (i.e., Chief or Sheriff), a Lieutenant, four Sergeants, seven Detectives, two Agents, and three patrol officers. The majority of officers were assigned to units at the county or departmental level, primarily focused on the detection, prevention, and enforcement of violent crime. Inversely, one county Detective was specialized in firearm investigations, and one Agent's primary focus was drug enforcement.

\section{Table 1}

Interview participant description

\begin{tabular}{llllll}
\hline Name & Gender & Race & $\begin{array}{l}\text { Service } \\
\text { Length }\end{array}$ & Rank & Location \\
\hline Joshua & Male & White & 17 & Detective & Coconut County Sheriff's Office \\
Owen & Male & White & 18 & Detective & Coconut County Sheriff's Office \\
Ryan & Male & White & 19 & Sergeant & Coconut County Sheriff's Office \\
Calvin & Male & Black & 5 & Officer & Needle City PD, Queen County \\
Daniel & Male & White & 12 & Sergeant & Needle City PD, Queen County \\
Emily & Female & White & 22 & Chief & Needle City PD, Queen County \\
Jennifer & Female & White & 4 & Officer & Needle City PD, Queen County \\
Jonathan & Male & Black 10 & Officer & Needle City PD, Queen County \\
Luke & Male & White & 30 & Outgoing Chief & Needle City PD, Queen County \\
Andrew & Male & White & 26 & Detective & Queen County Sheriff's Office \\
Gabriel & Male & Black & 10 & Agent & Queen County Sheriff's Office \\
Jacob & Male & White & 46 & Deputy Chief Sheriff & Queen County Sheriff's Office \\
Jack & Male & White & 15 & Detective & Queen County Sheriff's Office \\
John & Male & White & 25 & Detective & Queen County Sheriff's Office \\
Kevin & Male & White & 19 & Sergeant & Queen County Sheriff's Office \\
Logan & Male & White & 6 & Detective & Queen County Sheriff's Office \\
Michael & Male & White & 37 & Detective & Queen County Sheriff's Office \\
Noah & Male & White & 31 & Sergeant & Queen County Sheriff's Office \\
Tyler & Male & White & 29 & Senior Agent & Queen County Sheriff's Office \\
Samuel & Male & Black & 20 & Lieutenant & Queen County Sheriff's Office \\
\hline
\end{tabular}


In addition to shadowing and interacting with officers formally and informally through fieldwork observations, semi-structured interviews were also conducted. Interviews were completed with frontline officers, their immediate supervisors, and other officers from the same unit and/or department. All interviews were conducted with the participants individually and were completed in the officers' or the researcher's working environment, providing some seclusion from co-workers. To facilitate interviews, a loose protocol was developed. In doing so, the protocol provided structure to the interview, while also enabled participants the ability to guide discussions and fully express their opinions. This method was selected to provide officers with a voice regarding changes in citizen engagement, perceptions of policy changes, and the impact on law enforcement post-Ferguson. Interview questions centered around the impact of recent events on officer confidence, morale, and policing strategies. With the informed consent agreement, pseudonyms are utilized in the forthcoming results section to describe the participants; however, officer ranks are provided for contextual purposes.

\section{Analysis}

To analyze the data more efficiently, interviews were audio recorded and transcribed. The data from the interview transcriptions and observer's field notes were anonymized, which participants were made aware of when presented with the informed consent agreement. A thematic analysis of data sets was conducted. First, a team of three additional researchers engaged in an inductive approach to open and axial coding to identify the most salient themes (Strauss \& Corbin 1998). Throughout this process, individual coding conducted by each of the research team was compared and discussed in order to ensure the confirmability and trustworthiness of emerging themes (Lincoln \& Guba, 1985). Second, overarching themes were interpreted in light of the existing literature relating to procedural justice, legitimacy, and the impact of the "Ferguson Effect". Thus, our inductive approach to data analysis was in keeping with the interpretative paradigm suited to privileging participants' perspectives on the common themes that emerged from the data (Deuchar et al., 2019). The purpose of our inductive approach to data analysis was to maintain the interpretative paradigm suited to privileging participants' perspectives on the common themes that resulted from the data. In this paper, we focus on presenting emerging insights from the interviews and informal discussions with officers (with the latter emerging during participant observation and recorded in field notes). In particular, we were most interested in officer perceptions that emerged regarding their attributions for crime, their declining legitimacy, and the breakdown of justice in the post-Ferguson era.

\section{Results}

Based on this methodology, the emerging findings were that crime, declining legitimacy, and breakdowns in justice were perceived by participants to be caused by the failings of several social institutions, including 1) home life, families, and parents, 2) the media, and 3) the community (and its residents). Breakdowns in justice refer to the condition in which the public are unwilling to communicate with the police, and when the public don't trust the police or give them information, it is difficult for police to solve crimes.

\section{Home Life, Families, and Parents are to Blame}

Home life, families, and parents were often the target of officer ridicule. In fact, the researcher's field notes and 13 of the 20 interviews discussed this theme. Noah, a sergeant with 
more than three decades of law enforcement experience, reported that there has been a, "breakdown of the home". Similarly, Sergeant Kevin, who had nearly two decades of law enforcement experience, asserted that, "there's a lot of parents who don't do their job at home". According to Chief Deputy Jacob and Detective Michael, who collectively had more than 80 years of law enforcement experience, this included an absence of "accountability" and "guidance" in the family (respectively). Many of the officers attributed these issues to, "weakening family social bonds" and disruptions in "family structure" (e.g., Agent Tyler and Chief Emily, respectively). "Single parent households" and families with "no father" were also referenced in this context by officers (e.g., Lieutenant Samuel and Officer Jennifer, respectively). Four officers felt that family issues were passed down in the family over time. Sergeant Daniel, who had a dozen years of law enforcement experience, stated,

I would say a lot of crime comes from generational influences. You are raised in a family where your father, your aunts, [and] your uncles are committing crimes and it is generational. So, you wanna talk about family values; if your family is committing crimes, what other ways do you know? So, they, kind of, are born into the lifestyle they live in.

Family issues, in several of the officer interviews, were most attributable to conditions of poverty.

In absence of quality parenting and presence of poverty, some officers stepped into family roles. Officer Jennifer, with 4 years of law enforcement experience, declared, "we're [law enforcement] acting as parents". This responsibility, however, was seen by some officers as outside the scope of their duties. Detective Andrew, who had more than a quarter century of law enforcement experience, proclaimed that, "we can't fix the family" and Sergeant Kevin noted that, "we are not here to be parents" in the researcher's field notes.

The problem is with the young dudes, the ones who are about 13-21 - they got no father figures, no guidance, they're out here selling drugs, carrying guns, robbing people. (Field Observations, p. 51)

Moreover, overstepping their role was perceived by four officers as contributing to contentious police-parent interactions. Officer Calvin, who had five years of law enforcement experience, admitted, that "Parents don't want nobody else talking to their child, dealing with their child cause then they wanna come over and fight or 'why'd you say this to my child', or whatever the case, which is sad". Substantively, the officers acknowledged home life, families, and parents shared some of the responsibility for crime, their declining legitimacy, and breakdowns in justice.

\section{News Media is to Blame}

Additionally, news media (print, visual, and social) received a lot of negative attention in the researcher's field notes and from all of the interviewed officers. In fact, there was somewhat of a consensus for Sergeant Kevin's contention that, "the media is the biggest problem". More specifically, officers perceived the news media as overgeneralizing their profession. Detective Michael, for example, suggested that there is an, "occasional bad police officer but they [(news media)] have painted the police like we're all bad". Officer Jennifer felt that these generalizations were inappropriate and asserted that, "even when we've had issues nationwide, we haven't experienced that same level of resistance here in our community". In this context, officers took 
issue with the news media's treatment of law enforcement as a monolithic group. Officer Jonathan, who had a decade of law enforcement experience, announced that, "law enforcement, as a whole, is not the same, you known. You're never gonna receive the same level of service, the same level of professionalism from officers".

Offices also remarked that the news media sensationalized events. To this point and relating to the public's response to officer-involved shootings outside their jurisdiction, Sergeant Ryan, who had nearly two decades of law enforcement experience, professed that,

If you watch CNN and NBC and even Fox, they make it like it's this huge, huge riot right, burning down all these buildings and there's all these fights and all these problems. But if you actually go down into those areas you're really talking about a block or two or three blocks. It's a very small area where this is actually occurring.

Similarly, Detective Andrew believed that regardless of officer innocence in use-of-force incidents, officers frequently found themselves in the news media spotlight when he indicated that, "you can shoot a guy with a gun in his hand pointed at you right now and you may still be on the front page of the paper". In this context, Detective Jack, who had fifteen years of law enforcement experience, reported that police are "under a microscope". He went on to elaborate that,

Unfortunately, the media and the public don't give law enforcement the same, I wouldn't necessarily say rights, like a joe-shmoe citizen, but if we do something that they don't agree with, they're already convicting us [(law enforcement)] before we even go to trial and they're always undermining our split-second decisions. They're already saying we're guilty, [and] 'why are you violating people's rights?'. We all have families that we want to go home to every day and we do have a split-second decision to make life altering decisions.

Moreover, offices held that the news media overemphasized negative policing stories, while neglecting positive stories. Detective Joshua, who had 17 years of law enforcement experience, communicated that, "the media will pick the stories where it's questionable [but] you don't see where a law enforcement officers saves a kid from a burning building". Furthermore, some officers noticed that the news media's format does not provide proper context to police events. Detective John, who had 25 years of law enforcement experience, stated,

Policing's a dirty job. It's ugly. You know what I mean? And when you [(news media)] show it to the public, you know they aren't used to that. They don't understand that. They give the benefit of the doubt to the bad guy most of the time. So, that's making it a lot tougher.

In field observations, Mitch was asked about the impact that the Ferguson shooting and the media coverage has had.

'I think there are quite a lot of guys out there who are gettin' trigger shy because of the media attention - and that can actually cause more of a risk in some situations, if they hesitate. (Field Observations, p. 64) 
In these distortions of police work, a couple of officers understood that the news media sought to polarize viewers/readers, like Sergeant Daniel who wished, "that somehow we can eliminate the media portrayal of everything going on with the far-left and the far-right". This led Officer Calvin to find police work to be in a no-win situation. He enunciated that, "regardless of if you're doing something right, from somebody else's perception, they're [(the public is)] going to think you're [(police are)] doing something wrong". Consequently, Sergeant Noah declared that it is, "no longer news" because it more resembles "opinions" and "political stances". Substantively, news media was seen as contributing to deficits in police-community perceptions.

\section{The Community (and its Residents) are to Blame}

Perhaps the most visceral responses from the officers were directed at the community and its residents. In fact, the community's role in fostering crime, declining police legitimacy, and breakdowns in justice was discussed by all of the officers and found in the researcher's field notes. Agent Tyler, who had nearly three decades of law enforcement experience, described some of the areas he policed as "poison communities", while Sergeant Noah insisted that there has been a "breakdown of the community" particularly relating to "morals". In many of the communities that were discussed, the officers felt that the conditions were truly dire, and used warzone terminology to describe them, such as an "area of combat" (Agent Tyler), "first-line of defense" (Detective Logan), and framed gangs as "an insurgency" (Sergeant Ryan), "a terrorist organization" (Sergeant Noah), and "domestic security threat" (Agent Gabriel). Substantively, Detective Jack, in the researcher's field notes, thought that, "there is no escape from these communities" and Detective Andrew corroborated that community residents were "stuck".

Officers that embraced community police were chastised by their peers. James, for example, stated, "I am seen as a 'huge-a-thug' at time". The 'huge-a-thug' characterization of officers who embrace community police was also repeated in the researcher's field notes. Negative attitudes were often contextualized in poor police-community relationships. To this point, Officer Calvin recognized that, "we're [(police)] not liked", "the community's fed up", and "we've definitely lost respect". Similarly, Officer Jennifer admitted that, "we're [(police)] not in a time that we're overly supported" and Officer Jonathan confirmed that, "there is tension" with communities. Sergeant Kevin believed that all resident-police encounters are negative when he disclosed that, "even if you're not committing crimes, let's be honest, you don't have a positive interaction with law enforcement".

\section{Well, instead of being angry at people if they catch someone, they should want to help - instead of going against us, they shouldn't be mad and do extra staff to help us.' Again, it occurs to me just how insightful this young black man is. (Field Observations, p. 24)}

A considerable number of officers deduced that communities do not have confidence in the police. In public spaces, Detective Joshua divulged that there are times, "you just have the entire crowd against you".

In their assessments, the officers regularly noted that a few communities lacked collective efficacy or an ability to self-regulate themselves. Officers, from their experiences, gathered that communities needed greater direction. In this instance, Detective Michael articulated that, "these kids don't have any leadership or any guidance or any community support". Agent Tyler explained how collective efficacy has changed over time: 
I grew up in the housing projects and if you did something, you know everybody knew who you were and your mother and father would find out before you had the chance to tell them. So, people kind of looked after each other. But now, it just seems that people are just wanting to get after what they want and if it means bending a few rules or just breaking them, they don't seem to have the hesitancy that they used to.

Though maintaining community standards requires work, Detective Logan, who had six years of law enforcement experience, stated, that "they [(communities)] don't want to be inconvenienced".

The officers were also somewhat critical of community efforts to mobilize. In response to growing distrust between the police and community, for example, residents in one of the County areas began peace marchers. Sergeant Noah admonished the peace marches as, "beautiful wallpapering. They're a beautiful thing to show that there is a heart to the people in the area" but he was quick to indicate, "that heart doesn't transfer to the heart of the people doing the crimes". Detective Logan felt that the peace marches were a distraction to community interventions that have been shown to work. He expressed that,

they [peace marches] are ineffective. What they need to do is go out and actually do something for their community. Don't go and march about something. Go out and start an aftercare program, or an after-school program, or give something to get these kids off the street corner.

Community mobilization, in the face of officer involved shootings, were further scrutinized by the officers. Chief Luke, who had 30 years of law enforcement experience, perceived peace marches to be inviting protesters, "from outside" the community and he feared, "professional protesters" would cause problems because "some do it violently". Officers were particularly cynical of the Black Lives Matter (BLM) movement, like Sergeant Noah who suspected that the BLM movement was increasing the violence on police when he asserted, that "it may not be about love and peace anymore. [...] Cops are being killed because we're the bad guys and Black Lives Matter".

Though community policing has been promoted in the extant literature as a way of overcoming police-community issues, numerous officers surmised that community policing was not working, such as Agent Tyler who mentioned, "I don't think it [(community policing)] is an effective technique". Detective John went further to declare that community policing "is all a farce". Officers that embraced community policing were chastised by their peers. Officer Jonathan illustrated this phenomenon when he stated, "I am seen as a, 'hug-a-thug' at times". Chief Deputy Jacob noted that during his career conversations with members of the community were discouraged. He remarked that, "When I started, they would gauge the amount of work you did by the amount of miles on your car. They didn't want you out of your car" interacting with the public. He went on to recount an instance where he did get out of his car:

I had a group of kids in one neighborhood and they were some kids committing robberies. So, one day I went behind the school and some kids were shooting baskets. Well, I got out of my car and I started shooting baskets with them. I took my gun belt and put it in the trunk and these kids are twelve, thirteen, fourteen, years old. I put my gun belt in the back so I could move around a little bit and a crusty old sergeant came around the 
corner and caught me back there. I almost got fired. He didn't want to hear that I was building a relationship and that the relationship I built led to solving fifteen burglaries.

Agent Gabriel, who had 10 years of law enforcement experience, sensed that community policing was primarily used to overcome public relations blunders with the following statement:

The only time you'd see the local law enforcement agencies get involved in community policing activities when - oh gosh - we get in trouble 'cause this officer either got arrested or this officer shot somebody. [... The] next thing you know, they're on the news trying to do a community event to cover it up. I mean to be honest and it's the truth. I hate to throw my trade under the bus, [but] it's true.

Poor police-community relations, according to the officers, had led to greater verbal and physical defiance from the public. Lynn:

It really depends how they tell us things. If young people are respectful, I'm more willing to listen. But if they come across as angry and aggressive, then I'm more likely to shut down. (Field Observations, p. 28)

Detective Joshua who reported that, "the non-compliance is at a level that I never ever thought it could be at - never-ever. Everything is confrontational immediately". Agent Tyler agreed that the public is "getting more bold", "combative", and giving officers greater "resistance". This, he concluded was causing, "more confrontations" and did "make things hard" for police. Chief Luke established that, "they [(the public)] don't cooperate with police" and professed that "they want to take matters into their own hands". Likewise, Officer Jennifer interpreted things as, "that people are more angry, right now, and there's a little bit of resistance" from the public. Detective Owen, who had 18 years of law enforcement experience, suggested that the death of Michael Brown was an important benchmark for change in police-community relations with the following statement:

I would say post-Ferguson, there's more of a challenge. [The public says,] "you don't have the right to stop me" [or] "I'm filming" [...] and they're not paying attention to anything you're saying because they got their phone in your face and they're trying to Facebook live or periscope it [(i.e., the encounter)].

In this regard, several officers credited the public for escalating encounters. Sergeant Joshua stated that some community members made "very poor choices that make them a threat to the public", whereas Detective Andrew proclaimed that this context is, "a recipe for more [police] shootings".

Rebuilding community trust was also at the forefront of these discussions, like when Officer Jennifer confirmed that her agency placed an emphasis on the need to be perceived as legitimate:

That's always one of our big things right now, is to work on buy-in from the community. So, that is one of our big pushes right now because, honestly, we could be out there every day walking door-to-door. We could 
search every house and take every gun but next week they'd be back if you don't have that support from the community. So, right now one of our big pushes is to get the support from the community.

Chief Deputy Jacob affirmed that it was necessary to be entrusted by the community. To this point, he admitted, "we can't do it ourselves". Sergeant Daniel, however, cautioned that garnering community confidence is "not an overnight type of thing. [...] It's actions speak louder than words", whereas Detective John reminded the interviewer that "they [the community] have to have us".

\section{Discussion}

In this paper, we have attempted to respond in part to the relative paucity of existing scholarship focusing on law enforcement officers' perceptions about members of the public by drawing on qualitative insights emerging within the context of a wider study conducted in a Southern American State. In highlighting the voices of a diverse range of 20 participating officers, we have explored their perspectives regarding attributions for crime, declining police legitimacy, and the breakdown of justice.

Firstly, our insights have revealed the way in which the participating officers appeared to attribute an apparent increase in criminal activity combined with breakdowns in justice to their observations relating to weakening family bonds, reduced accountability, and a general lack of supportive guidance within the family home. They also perceived there to be a greater propensity towards confrontation from local citizens in the areas where they policed and a tendency towards filming of police practices that had led to greater public resistance to authority (Deuchar, Crichlow, $\&$ Fallik, 2020). These are important insights, given the evidence that suggests that the perceptions that the police have about the general public tend to guide officers' behavior during interactions with them (Jackson \& Wade, 2005; Jackson et al., 2015), and that those officers perceiving greater public antipathy may have increased cynicism and adopt more coercive attitudes towards citizens (Marier \& Moulde, 2019).

Previous policing scholarship has suggested that the distinguishing features of police culture are often characterized by an "us vs. them" mentality and include distrust and suspicion, cynicism, authoritarianism, and coercion (Reiner, 2010; Crank, 2014; Marier \& Moulde, 2019). Marier and Moulde (2019) identify that officers who perceive hostility from the public may become even more cynical and ultimately withdraw from the public into "fraternal solidarity" (p. 852). In turn, they may be more likely to justify the use of coercive tactics, thus producing threats to democratic policing (Marier \& Moulde, 2019). Our participating officers' perceptions regarding increased public hostility in the post-Ferguson era and their corresponding cynicism in relation to declining family values and lack of collective efficacy appeared to be accompanied by distrustful attitudes towards the public and a culture of solidarity where they drew upon military, warzone terminology to describe the communities they served.

Secondly, our empirical data also suggests that the officers felt that a strong culture had emerged where police officers had become demonized by the national media, and in turn that police legitimacy had increasingly become questioned within communities (Maguire, Nix, \& Campbell, 2017; Todak, 2017; Deuchar et al., 2020). They evidently believed that their profession was continually under the microscope and were hostile towards what they viewed as the increasingly common practice among citizens to film police behavior on cell phones and post these films online (Deuchar, Fallik, \& Crichlow, 2019; Deuchar et al., 2020). As Wilson (1973, p. 28) has highlighted, police often "exaggerate the extent of citizen hostility" and, combined with their tendency towards 
selective perception and confirmation bias, create a set of negative perceptions about the public (Trope \& Bassok, 1982; Klayman \& Ha, 1987; Worden, 1994).

Our officers' perceptions regarding the apparent linkages between negative news reporting and the undermining of police legitimacy emerging as a result of increased public scrutiny and digital activism had evidently further deepened their distrust of the public they served. Building on this, the strong levels of cynicism emerging from the officers' narratives became focused at times on the BLM movement, with some evidently perceiving it to be damaging and the source of increased violence towards officers. While some were evidently committed to community policing, there was a sense that this was still discouraged within the context of broader police culture. This is consistent with the traditional policing mindset discussed by Van Maanen (1978), whereby forceful and uncompromising conduct was viewed as an essential part of "real police work" (p. 227). It has been found that, among some American police officers, there is a belief that too much community policing could potentially embolden criminals, and that a warrior mindset is needed to sustain a distinction between officers and civilians (Rahr \& Rice, 2015; Deuchar, Crichlow \& Fallik, 2021, forthcoming).

Accordingly, the collective insights we have gathered from our data suggest that, for those officers sampled, there were strong elements of blame emerging for (perceived) increased crime rates, breakdowns in justice and the apparent ongoing crisis of legitimacy that American policing finds itself experiencing (Wallace White, Gab, \& Todak, 2017). The family unit and its apparent declining values, the tendency towards citizen journalism within the context of social media, the politicization of policing by the mass media and the emergence of a "new civil rights movement" (Maguire, Nix, \& Campbell, 2017, p. 740), galvanized by the BLM movement were collectively seen as being at the root of these issues. The externalizing of blame, combined with the tendency to cling on to traditional and enduring elements of policing culture, were apparently deepening an adversarial mentality.

\section{Policy Implications}

It has been argued that increased public scrutiny may help to improve police accountability through the subjective lenses of smart phones and the sharing of online content, as well as through intense media coverage of high-profile officer shootings and use-of-force incidents (Deuchar et al., 2019; Deuchar et al., 2021, forthcoming). However, some political commentators such as Heather MacDonald have claimed that officers are conscious of the negative publicity surrounding their profession, and have become less willing to do their job as a way of avoiding the likelihood of being accused of racial profiling or excessive force (Wolfe \& Nix, 2016). In a more general sense, some believe that the negative portrayal of policing in the media is foreshadowing relationships between members of the public and law enforcement officers in racial and ethnic minority communities, thus further aggravating police-community tensions (Goldsmith, 2015; Shjarback et al., 2017). Although we need to be cautious in terms of generalizing the insights from our empirical research, the perceptions emerging from our interviewees suggest that law enforcement officers may be responding to the increased levels of scrutiny, accountability, and negative media portrayal through cultivating a culture of blame, and in turn immersing themselves further within the protective blanket of traditional police culture characterized by cynicism and fraternal solidarity. The risk is that the further entrenchment of this culture may give rise to added justification for the very type of coercive tactics that fueled high profile incidents like those involving Michael Brown, Eric Garner, Freddie Gray, and - most recently - George Floyd.

As we have highlighted in this paper, police perceptions about public antipathy can often be inaccurate, driven by media attention and not actual public perceptions (Nix \& Wolfe, 2016; 
Nix \& Pickett, 2017). Just as members of the public are more likely to remember difficult or unpleasant encounters with law enforcement officers as opposed to routine ones, officers are more likely to remember hostile engagements with the public (Trope \& Bassok, 1982; Klaymand \& Ha, 1987; Worden, 1994). Marier and Moulde (2019) argue that police organizations must find ways to "mitigate or minimize perceptions of public hostility among officers" (p. 852).

As suggested previously, officer morale is an important concern given its apparent influence on officer perceptions of the public, as well as their general approach to the job of policing. Evidence suggests that where police leadership treat officers with respect, fairness, kindness, and consideration, this can contribute to procedural justice and officer commitment to policing reform (Wolfe \& Nix, 2016; Rosenbaum \& McCarty, 2017). Marier and Moule (2019) also argue that practices of organizational justice may be useful for helping officers deal with public criticism and resistance. Police leaders need to ensure that they not only put in place robust plans to enhance the motivation and morale of officers, but that a culture change is initiated to ensure that the traditional preferred focus on self-reliance, aggression, toughness, and independence is replaced by one that encourages officers to open up about their experiences of stress, demotivation, and psychological tension (Soomro \& Yanos, 2019). In so doing, if officers are exposed to an internal ethos of compassion, kindness, and respect they may be less sensitized to focusing on only negative interactions and feedback from the public and in turn become more open to embracing the "guardian" - as opposed to "warrior" - mindset recommended by the President's Taskforce for $21^{\text {st }}$ Century Policing $(2015$, p. 1) as a means of building trust and legitimacy with the public.

In addition, given that our insights support wider evidence suggesting that officers' perceptions of public antipathy may be largely driven by dominant media narratives (Nix \& Pickett, 2017), police leaders have an obligation to actively try and correct officers' sometimes mistaken assumptions regarding the public. Marier and Moule (2019) draw attention to the discrepancy between actual public support and officers' perceptions of public support, given that 76 percent of Americans express a "great deal" of respect for the police (McCarthy, 2016). Thus, regular inservice training needs to place an emphasis on ensuring that officers are made aware that their perceptions regarding stigma are not completely warranted, thereby helping to mitigate against further entrenching a culture of cynicism, distrust, and the favoring of coercive control (Reiner, 2010). At the same time, we cannot overlook the need for implicit bias training in police departments, as a means of also helping officers to recognize how deeply embedded and often unconscious bias affects judgments, and in turn stifles more positive interactions between officers and local citizens, most especially in communities of color (Deuchar et al., 2021, forthcoming).

\section{Conclusion}

We do of course, recognize the limitations of the research outlined in this paper. For instance, our fieldwork was confined to one Southern State within the US. Within this, the vast majority of the officers we interviewed were located in one County within that State, and were serving neighborhoods whose demographics were consistent with national rates. Also, as noted in the literature review, police are not a monolithic entity with homogenous beliefs, so capturing a conclusive picture of all police perception would be difficult even with a more representative sample. There also is likely a self-selection bias regarding the officers who volunteered to be observed and interviewed. However, we believe that the qualitative approach we adopted which privileged the voices and perspectives of these officers has led us to draw attention to some important emerging issues regarding officer perceptions about the public, the way in which elements of media reporting and entrenched cultural policing ideals may influence and interact with 
these and how police leadership and training needs to evolve in order to enhance police-community relations.

On May 25, 2020, a White Minneapolis Police Department officer killed George Floyd, a 46-year-old Black man, by kneeling on Floyd's neck for seven minutes and 46 seconds while he was handcuffed, lying prone, and pleading for his life, with cries of "I can't breathe" (Kiang \& Tsai, 2020; Nwonka, 2020). The nature of the killing, occurring within the long-standing context of racial disparities in police violence against black people, led to an unprecedented public response (Kiang \& Tsai, 2020). Floyd's death stimulated a series of protests in cities around the US, bringing a "new wave of attention to the issue of inequality within criminal justice" and new demands for policing reform (Dave et al., 2020, p. iii). Given our arguments that suggest that entrenched perceptions about public antipathy may lead to greater officer cynicism and the deepening of coercive attitudes towards citizens, now more than ever an imperative element of police reform is for police leaders to support their officers and encourage them to adopt positive and healthy attitudes towards those they serve.

It is noteworthy that positive interactions with the public are one of the key motivations for people seeking careers as police officers. The top reasons given by police, in ranked order, are the opportunity to help people, job security, the excitement of the work, to fight crime, and the prestige of the profession (Foley, Guarneri, \& Kelly, 2008). These have remained stable over time, and there seems to be no significant racial/ethnic or gender differences in these motivations. Despite the lofty tenor of these virtues, it is important to continue striving towards the ideals that could inspire the next generation of police officers. Indeed, the task of achieving such aspirations is beleaguered by the racial, cultural, political, and geographical differences that often shape perceptions in American life. Such perceptions at times seem to be deeply rooted and impenetrable, and the polarized nature of the heated national debates grow more and more disheartening. Nevertheless, future research should explore the distinctions between various clusters within policing, such as by rank, gender, and race, and also seek to quantify the strength and direction of the relationships between police perceptions of legitimacy and causes of crime, should also focus on unpacking officer perceptions about the public and how these may play out differently across America's cognitive landscape. The lessons learned in this paper should lead to further understanding of this topic not only in the US, but international settings as well.

\section{References}

Adams, I. \& Mastracci, S. (2019). Police body-worn cameras: Effects on officers' burnout and perceived organizational support. Police Quarterly, 22(1), 5-30.

Adams, J. (2019). "I almost quit": Exploring the prevalence of the Ferguson effect in two small sized law enforcement agencies in rural southcentral Virginia, The Qualitative Report, 24(7), 1747-1764.

Ajzen, I. \& Fishbein, M. (1977). Attitude-behavior relations: A theoretical analysis and review of empirical research. Psychological Bulletin, 84(5), 888-918.

Bates, L., Antrobus, E., Bennett, S., \& Martin, P. (2015). Comparing police and public perceptions of a routine traffic encounter. Police Quarterly, 18(4), 442-468.

Bonilla, Y. \& Rosa, J. (2015). \#Ferguson: Digital protest, hashtag ethnography, and the racial politics of social media in the United States. American Ethnologist, 42(1), 4-17.

Bureau of Justice Statistics (2013). Law Enforcement Management and Administrative Statistics. Washington, D.C.: Department of Justice.

Campbell, B., Nix, J., \& Maguire, E. (2018). Is the number of citizens fatally shot by police increasing the post-Ferguson era?, Crime \& Delinquency, 64(3), 398-420. 
Carr, J. \& Maxwell R. (2018). Police officers' perceptions of organizational justice and their trust in the public. Police Practice and Research, 19(4) 365-379.

Cordner, G. (2017). Police culture: Individual and organizational differences in police officer perspectives. Policing: An International Journal, 40(1), 11-25.

Crank. J. (2014). Understanding Police Culture (2 $2^{\text {nd }}$ ed.). London: Routledge.

Daragahi, B. (2020). Why the George Floyd protests went global, Atlantic Council, [online] 10 June, Available from: https://www.atlanticcouncil.org/blogs/new-atlanticist/george-floydprotests-world-racism/.

Dave, D., Friedson, A., Matsuzawa, K., Sabia, J. \& Safford, S. (2020). Black Lives Matters protests, social distancing and COVID-19, Center for Health, Economics and Policy Studies: Working Paper Series. San Diego: San Diego University.

Davis, E., Whyde, A., \& Langton, L. (2018). Contacts Between Police and the Public, 2015. NCJ 251145. Washington, D.C.: U.S. Department of Justice.

Deuchar, R., Crichlow, V. \& Fallik, S. (2020). Cops in crisis?: Ethnographic insights on a new era of politicization, activism, accountability and change in transatlantic policing. Policing and Society, 30(1), 37-64.

Deuchar, R., Crichlow, V., \& Fallik, S. (2021, forthcoming). Police-Community Relations in Times of Crisis: Decay and Reform in the Post-Ferguson Era. Bristol: Bristol University Press.

Deuchar, R., Fallik, S., \& Crichlow, V. (2019). Despondent officer narratives and the 'post Ferguson' effect: Exploring law enforcement perspectives and strategies in a Southern American State. Policing and Society, 29(9), 1042-1057.

Emerson, R., Fretz, R., \& Shaw, L. (1995) Writing Ethnographic Fieldnotes. Chicago: University of Chicago Press.

Fingerhut, H. (2017). Deep racial, partisan divisions in Americans' views of police officers. Pew Research Center.

Foley, P., Guarneri C., \& Kelly, M. (2008). Reasons for choosing a police career: Changes over two decades. International Journal of Police Science and Management, 10(1), 2-8.

Gaub, J., Choate, D., Todak, N., Katz, C., \& White, M. (2016). Officer perceptions of body-worn cameras before and after deployment: A study of three departments. Police Quarterly, 19(3) 275-302.

Goldsmith, A. (2015). Disgracebook policing: Social media and the rise of police indiscretion, Policing and Society, 25(3), 249-267.

Hammersley, M. (2006). Ethnography: Problems and prospects. Ethnography and Education, 1(1), 3-14.

Hammersley, M. \& Atkinson, P. (2007). Ethnography: Principles in Practice. London: Routledge.

Huq, A., Jackson, J., \& Trinkner, R. (2017). Legitimating practices: Revisiting the predicates of police legitimacy. British Journal of Criminology, 57(5), 1101-1122. doi: 10.1093/bjc/azw037

Ingram, J., Paoline, E., \& Terrill, W. (2013). A multilevel framework for understanding police culture: The role of the workgroup. Criminology, 51(2), 365-397.

Intravia, J., Wolff, K., \& Piquero, A. (2018). Investigating the effects of media consumption on attitudes toward police legitimacy. Deviant Behavior, 39(8), 963-980.

Ioimo, R., Becton, J., Meadows, L., Tears, R., \& Charles, M. (2009). Comparing the police and citizen views on biased policing. Criminal Justice Studies, 22(2), 123-140.

Jackson, A. \& Wade, J. (2005). Police perceptions of social capital and sense of responsibility: An explanation of proactive policing. Policing: An International Journal of Police Strategies and Management, 28(1), 49-68. 
Jackson, J. \& Bradford, B. (2019). Blurring the distinction between empirical and normative legitimacy? A methodological commentary on 'police legitimacy and citizen cooperation in China'. Asian Journal of Criminology. 14:265-289 doi.org/10.1007/s11417-019-09289W.

Jackson, J., Bradford, B., Kuha, J., \& Hough, M. (2015). Empirical legitimacy as two connected psychological states. In G. Mesko \& J. Tankebe (Eds.), Improving Legitimacy of Criminal Justice in Emerging Democracies. London, England: Springer.

Johnson, K. (2020). 'Naming and shaming': States stepping up enforcement of stay-at-home orders. USA Today. https://www.usatoday.com/story/news/politics/2020/04/16/coronavirusarrests-rise-police-enforce-stay-home-orders-states/5142415002/

Kiang, M. \& Tsai, A. (2020). Statements issued by academic medical institutions after George Floyd's killing by police and subsequent unrest in the United States: Cross-sectional study, MedRxiv. DOI: https://doi.org/10.1101/2020.06.22.20137844.

Klayman, J. \& Ha, Y. (1987). Confirmation, disconfirmation and information in hypothesis testing. Psychological Review, 94(2), 211-228.

Lee, M. \& McGovern, A. (2013). Force to sell: policing the image and manufacturing public confidence. Policing \& Society, 23 (2), 103-124.

Lincoln, Y. \& Guba, E. (1985) Establishing trustworthiness. Naturalistic inquiry, 289(331), 289327.

Maguire, E., Nix, J., \& Campbell, B. (2017). A war on cops? The effects of Ferguson on the number of US police officers murdered in the line of duty. Justice Quarterly, 34(5), 739-758.

Marier, C. \& Moule, R. (2019). Feeling blue: Officer perceptions of public antipathy predict police occupational norms. American Journal of Criminal Justice, 44(5), 836-857.

McCarthy, J. (2016, October 24). Americans' Respect for Police Surges. Washington, D.C.: Gallup. Available from: http://news.gallup.com/poll/196610/americans-respect-police-surges.aspx

Morin, R., Parker, K., Stepler, R., \& Mercer, A. (2017). Behind the Badge: Amid Protests and Calls for Reform, how Police View their Jobs, Key Issues and Recent Fatal Encounters between Blacks and Police. Pew Research Center.

Mourtgos, S. \& Adams, I. (2019). The rhetoric of de-policing: Evaluating open-ended survey responses from police officers with machine learning-based structural topic modeling. Journal of Criminal Justice, 64, 61-73.

Muir, W. (1977). Police: Streetcorner Politicians. Chicago: University of Chicago Press.

Murray, K. \& Harkin, D. (2017). Policing in cool and hot climates: legitimacy, power and the rise and fall of mass stop and search in Scotland. British Journal of criminology, 57 (4), 885905.

Namli, U. (2021). Behavioral Changes among Street Level Drug Trafficking Organizations and the Fluctuation in Drug Prices Before and During the Covid-19 Pandemic. American Journal of Qualitative Research, 5(1), 1-22. https://doi.org/10.29333/ajqr/9691

Niederhoffer, A. (1967). Behind the Shield. Garden City, New York: Doubleday \& Company, Inc.

Nix, J. \& Pickett, J. (2017). Third-person perceptions, hostile media effects, and policing: Developing a theoretical framework for assessing the Ferguson effect. Journal of Criminal Justice, 51, 24-33.

Nix, J. \& Wolfe, S. (2016). Sensitivity to the Ferguson effect: The role of managerial organizational justice. Journal of Criminal Justice, 47, 12-20.

Nix, J., Pickett, J., \& Wolf, S. (2020). Testing a Theoretical Model of Perceived Audience Legitimacy: The Neglected Linkage in the Dialogic Model of Police-community Relations. Journal of Research in Crime and Delinquency, 57(2) 217-259. 
Nix, J., Pickett, J., Baek, H., \& Alpert, G. (2017). Police research, officer surveys, and response rates. Policing \& Society, 29(5), 1-21.

Nwonka, C. (2020) The protests over George Floyd's death show how film and culture can be tools of anti-racism, but we must continue to value them beyond this moment, LSE USCentre [online]. Available from: https://blogs.lse.ac.uk/usappblog/2020/06/08/the-protests-overgeorge-floyds-death-show-how-film-and-culture-can-be-tools-of-anti-racism-but-wemust-continue-to-value-them-beyond-this-moment/

Paoline, E. (2003). Taking stock: Toward a richer understanding of police culture. Journal of Criminal Justice, 31(3), 199-214.

Paoline, E. (2004). Shedding light on police culture: An examination of officers' occupational attitudes. Police Quarterly, 7(2), 205-236.

Paoline, E. \& Gau, J. (2018). Police occupational culture: Testing the monolithic model. Justice Quarterly, 35(4), 670-698.

Perry, B. (2009). Impacts of disparate policing in Indian country. Policing \& Society, 19(3), 263281.

President's Task Force on 21st Century Policing (2015). Final Report of the President's Task Force on $21^{\text {st }}$ Century Policing. Washington, D.C.: Office of Community Oriented Policing Services.

Rahr, S. \& Rice, S. (2015) From warriors to guardians: Recommitting American police culture to democratic ideals. New Perspectives in Policing Bulletin. Washington, D.C.: U.S. Department of Justice, National Institute of Justice.

Reiner, R. (2010). The Politics of the Police ( $4^{\text {th }}$ ed.). Oxford: Oxford University Press.

Rosenbaum, D. \& McCarty, W. (2017). Organizational justice and officer "buy in" in American policing. Policing: An International Journal, 71-85.

Rouhania, S., Gudlavalletib, R., Atzmonc, D., Park, J., Olsond, S., \& Sherman, S. (2019). Police attitudes towards pre-booking diversion in Baltimore, Maryland. International Journal of Drug Policy, 65, 78-85.

Rozin, P., \& Royzman, E. (2001). Negativity bias, negativity dominance, and contagion. Personality and Social Psychology Review. 25, 296-320.

Saunders, J., Kotzias, V., \& Ramchand, R. (2019). Contemporary police stress: The impact of the evolving socio-political context. Criminology, Criminal Justice, Law \& Society, 20(1), 3552.

Shjarback J., Pyrooz, D., Wolfe, S., \& Decker, S. (2017). De-policing and crime in the wake of Ferguson: Racialized changes in the quality and quality of policing among Missouri police departments. Journal of Criminal Justice, 50, 42-52.

Skolnick, J. (2011). Justice Without Trial: Law Enforcement in Democratic Society (4 ${ }^{\text {th }}$ ed.). New Orleans, LA: Quid Pro Books.

Soomro, S. \& Yanos, P. (2019). Predictors of mental health stigma among police officers: The role of trauma and PTSD. Journal of Police and Criminal Psychology, 34(2), 175-183.

Stamati, T., Papadopoulos, T., \& Anagnostopoulos, D. (2015). Social media for openness and accountability in the public sector: cases in the Greek context. Government information Quarterly, 32 (1), 12-29.

Strauss, A. \& Corbin, J. (1998). Basics of Qualitative Research: Techniques and Procedures for Developing Grounded Theory. Thousand Oaks, California: Sage.

Sun, I., Li, L., Wu, Y., \& Hu, R. (2018). Police legitimacy and citizen cooperation in China: Testing an alternative model. Asian Journal of Criminology, 13(4), 275-291.

Todak, N. (2017). The decision to become a police officer in a legitimacy crisis. Women \& Criminal Justice, 27(4), 250-270. 
Trope, Y. \& Bassok, M. (1982). Confirmatory and diagnosing strategies in social information gathering, Journal of Personality and Social Psychology, 43(1), 22-34.

Tyler, T. (1990, 2006). Why people obey the law. New Haven: Yale University Press.

Tyler, T. (2004). Enhancing Police Legitimacy. The Annals of the American Academy of Political and Social Science, 593, (84-99).

Tyler, T. \& S. Blader. (2000). Cooperation in groups. Philadelphia: Psychology Press.

U.S. Census Bureau (2017). Quick Facts Data. Available from: https://www.census.gov/quickfacts/fact/table/US/PST045216

U.S. Department of Justice, Office of Community Oriented Policing Services. (2021). Procedural Justice. https://cops.usdoj.gov/prodceduraljustice

U.S. Department of Justice. (2015). Department of justice report regarding the criminal investigation into the shooting death of Michael Brown by Ferguson, Missouri police office Darren Wilson [online]. Available from: https://www.justicegov/sites/default/files/opa/pressreleases/attachments/2015/03/04/doj_r eport_on_shooting_of_michael_brown_1.pdf [Accessed 12 December 2017].

Van Maanen, J. (1978). The asshole, in: P. Manning \& J. Van Maanen (eds) Policing: A View from the Street, Los Angeles, CA: Goodyear Press, pp. 221-238.

Wallace, D., White, M., Gaub, J., \& Todak, N. (2018). Body-worn cameras as a potential source of depolicing: Testing for camera-induced passivity. Criminology, 56(3), 481-509.

Westley, W. (1970). Violence and the Police. Cambridge, MA: MIT Press.

White, M. \& Fradella, H. (2020). Policing a pandemic: Stay-at-home orders and what they mean for the police. American Journal of Criminal Justice volume 45, 702-717.

Wilson, J. (1973). Varieties of Police Behavior: The Management of Law and Order in Eight Communities. New York: Atheneum.

Wolfe, S. \& Nix, J. (2016). The alleged Ferguson effect and police willingness to engage in community partnership. Law and Human Behavior, 40(1), 1-9.

Worden, R. (1994). The 'Causes' of Police Brutality: Theory and Evidence on Police Use of Force. In And Justice for All: Understanding and Controlling Police Abuse of Force. Washington, D.C.: Police Executive Research Forum. Editors: Geller W. \& Toch, H. 


\section{Notes on Contributors}

Adam Dobrin earned his Bachelor's degree from the College of William and Mary in Virginia, both his Master's and Doctorate in Criminology from the University of Maryland. He is an Associate Professor in the School of Criminology and Criminal Justice at Florida Atlantic University, and volunteers as a reserve road patrol deputy in his local county sheriff's office. He has published on a range of topics, including juvenile correctional health-care issues, volunteer and community-oriented policing, as well as two books on violence data.

Dr. Seth Wyatt Fallik is the Undergraduate Program Coordinator and Assistant Professor in the School of Criminology and Criminal Justice at Florida Atlantic University. Additionally, he is an Affiliate Faculty for the Center for Urban and Environmental Solutions and Peace, Justice, and Human Rights Initiative at Florida Atlantic University. Much of Dr. Fallik's research involves ongoing researcher-practitioner collaborations and he has been published in criminal justice and criminology's top journals.

Ross Deuchar is Professor of Criminology and Criminal Justice in the School of Education and Social Sciences at the University of the West of Scotland, Affiliate Professor in the School of Criminology and Criminal Justice at Florida Atlantic University and a Fulbright Alumnus. He has published 6 authored books and numerous peer-reviewed journal articles and book chapters on his work on gangs, violence, gang desistance and the policing of gangs.

Vaughn J. Crichlow is an Associate Professor in the School of Criminology and Criminal Justice, and Interim Associate Dean in the College of Social Work and Criminal Justice at Florida Atlantic University. He received his Ph.D. in Criminal Justice from Michigan State University and holds a Law degree from the University of London. His research interests include international and cross-cultural comparisons in policing and crime prevention, police-community encounters with ethnic minorities, procedural justice and police legitimacy perceptions.

Sierra Harris is an Inspector Specialist with Florida Agency for Health Care Administration and law student at Nova Southeastern University. She graduated from Florida Atlantic University with a Master of Science in Criminology and Criminal Justice. Her areas of interest include criminal law and criminal justice reform.

Manuscript received April 19, 2021

Final revision received June 17, 2021

Accepted July 6, 2021 